トレーニング期分け論の形成・発展と今日的課題

\author{
村木 征人
}

\title{
Development and contemporary problems of the periodization in sport training
}

\author{
Yukito Muraki
}

\begin{abstract}
This paper reviews the processes of formation and development of periodization in the theory of sport training, and attempts to identify problems on which future study should be focused. A major criticism of the classical periodization theory of Matvejev was the realities of top-level sports activities, which have now approached the mature stage and become uncoupled from the theory. These are problems that have been taken up as future topics in the classic theory, but have not been thoroughly solved. One is the problem of training characteristics for each stage of athletic development, especially in the junior period and mature stage. Other problems have been related to training speciality due to classified sport events, especially speed-strength events and ball games. However, it cannot be ruled out that the development cycle of sport-form is an essential factor of periodization. Skepticism of analytical training study has been directed at the inseparable nature of exercise as basic training, being characterized by pleiotropy and polysemy. A new approach to solving this has been emerging in training studies, which discuss the effects of physiological load in training exercises specialized for technical and tactical training. The primary problem in future training studies will be the structuring of sports training and the competition system as a versatile preparation process for the improvement and stability of sports performances. In addition, integration of conditions and technical-tactical training will be indispensable.
\end{abstract}

Key words: training periodization, sport-form, training system, general theory of sport training

(Japan J. Phys. Educ. 44: 227-240, May, 1999)

キーワード：トレーニング期分け，競技的状態，トレ ーニングシステム、一般トレーニング論

1.はじめに

20世紀後半に於ける各種スポーツでの国際的 競技水準の高度化と専門化は，必然的に専門的な 指導者（米: Coach, 欧 : Trainer, 英 : Manager）の発生を促し, 同時に, その理論的基礎と
すべき指導および包括的なトレーニング原理に関 するトレーニング論 (Trainingslehre; theory of sport training）の必要性を高めて来た。この傾 向は必然的に，国家的スポーツシステムとして， 選手並びにコーチ養成制度を確立したソ連・東欧 の社会主義諸国に顕著であった。

図 1 は，戦後の陸上競技世界記録（男子）の 発達推移と主要な関連著作をプロットしたもので 


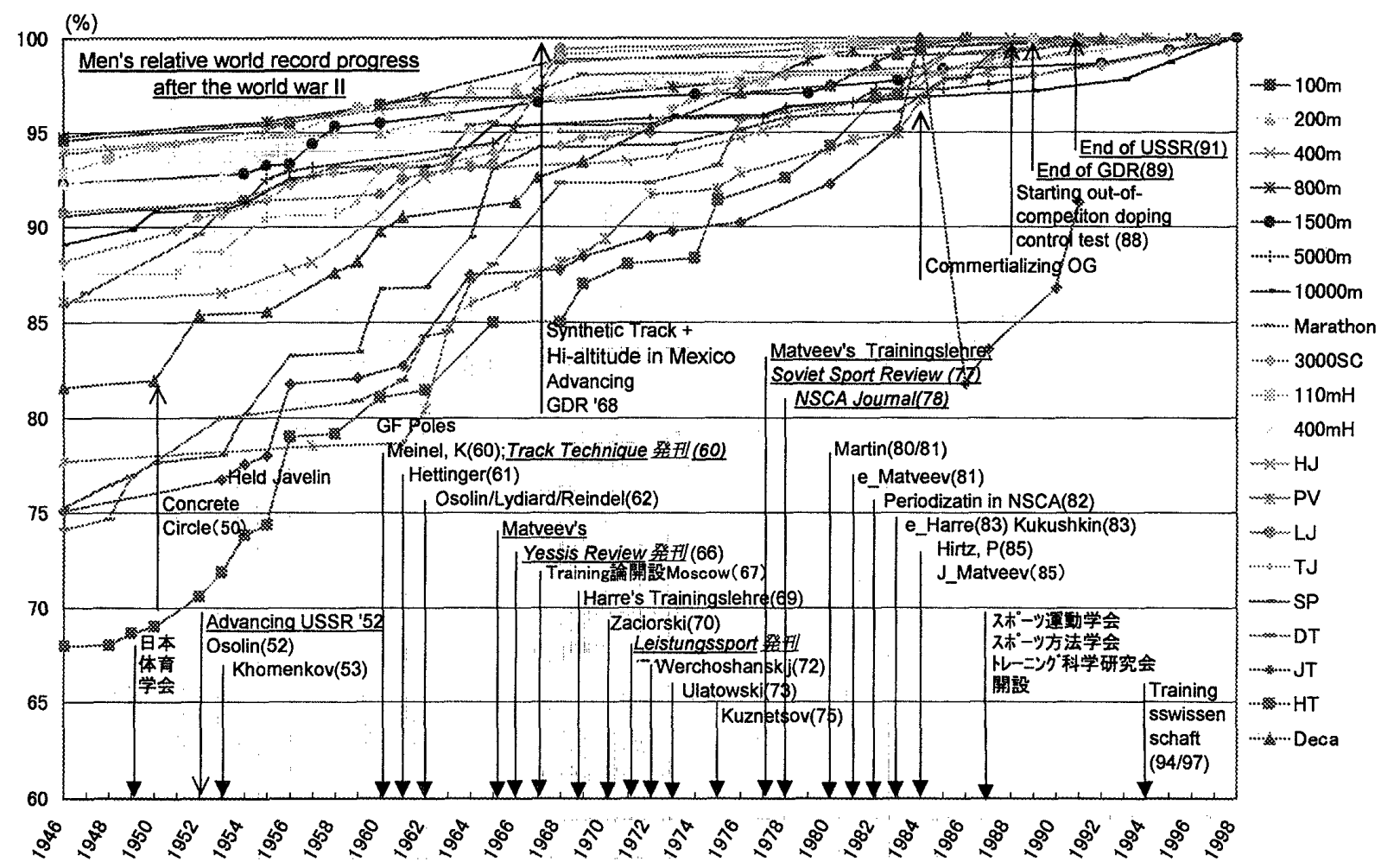

図 1 戦後の陸上競技世界記録（男子）の発達推移と主要なスポーツトレーニング論関連著作の発刊史（競技記 録は，種目間を比較するために1998年時点を100とする相対記録で示す).

める（種目間を比較するために1998年時点を 100 とする相対記録で示している).

戦後，急速に発展する競技スポーツによって直 面し始めた問題が，従来の体育理論の枠内での対 応と解決が困難となったのは，旧ソ連·社会主義 諸国ばかりでなく，西側の資本主義先進諸国でも 同様であった，それらは，特にトレーニング活動 の計画と立案, 競技成績 ·試合の分析, 適正な卜 レーニングの目的と内容, 並びにトレーニング負 荷の量と強度の間の適正割合等々に関してであ る. Ulatowski (1973) によれば，これらは明ら かに従来の「体育の科学」の範疇を越えるもので めり，スポーツに関連した様々な科学の複合的・ 総合的なアプローチを通してトレーニングの諸問 題の解決に当たり，それらをトレーニング現場に 提示する必要が生まれたのである。

国際競技力の向上を国家政策としたり連を中心 とする東側諸国では, 戦後スポーツでの世界征覇 を目指したスポーツ・システムを確立する中で，
制度化されたコーチ養成の理論的基礎を提供する 目的でスポーツ理論の体系化が進められた。これ は，スポーツの試合とトレーニング活動に直結し た科学的で実用的な知識構造を, 現代スポーツの 理論体系の中心的存在として位置付けようとする ものである. 一方, 西側の先進諸国ば近代スポー ツとオリンピック・ムーブメント発展の原動力で はあったが，コーチ養成システムの確立は不十分 のままであった。このため，個別スポーツ科学々 トレーニング理論は体系化されることなく, 前者 は個々の母体科学に依拠し, 後者は個別種目毎の 経験的方法論としてのみ発展して来たと言える.

トレーニング科学 (または論) は, 主に自然系 スポーツ科学 (スポーツ生理学, 解剖学, バイオ メカニクス, スポーツ栄養学, スポーツ医学, ス ポーツ心理学等）がトレーニング問題を学際的な 研究対象として扱う総称とされる. 特に日本で は, 依然として「体力」トレーニング論と同義と みなされている. しかし，それら分析的·要素的 


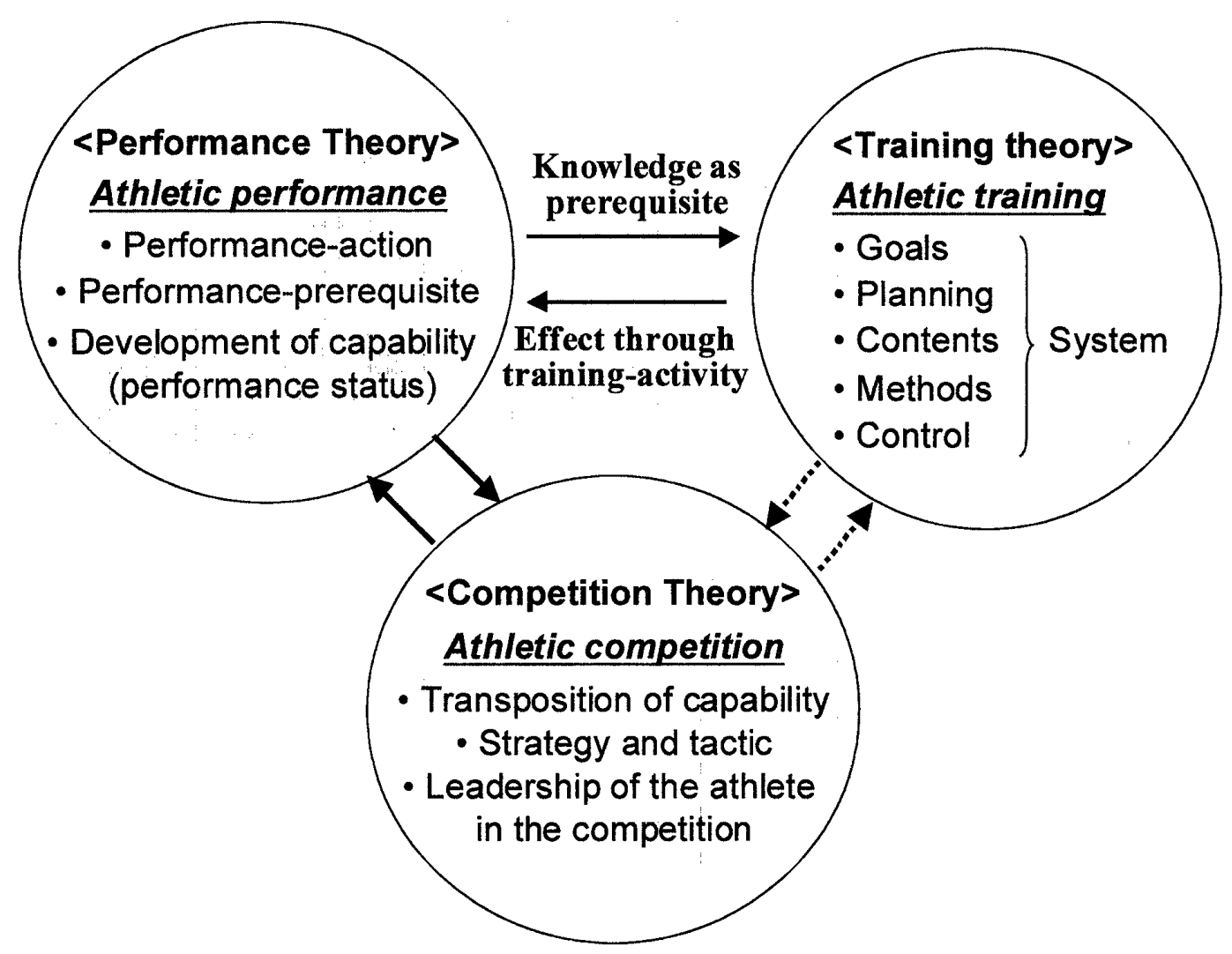

図 2 トレーニング科学が対象とする研究領域と内容の相互関係 (Schnabel, Eds., 1997, p. 17より村木英訳)

・客観的な科学的知見として得られたスポーツ科 学での理論的知識体系や法則が，競技者養成とス ポーツトレーニングの過程に求められる実践的な 諸問題に対してどれほど直接的な貢献を果たし得 たかは疑問である，殊に，競技パフォーマンスや トレーニングの構造性, トレーニング構成の原 理, 運動課題, トレーニング計画, 評価, 管理, トレーニング諸条件の影響等々, トレーニングと コーチングで直面する実際的な諸問題からの乘離 は「理論と実践のギャップ」として常に問題とさ れ，現場のコーチ：選手らにとっては隔靴掻㾕の 感が免れない所である。

おりしも，統合後10周年を迎えたドイツでは， 旧東ドイツ時代の実践系一般トレーニング理論家 が，西ドイツ化されたライプチッヒ大学での生さ 残りをかけ，トレーニング科学（Trainingswissenschaft）改訂 2 版を再度上样した（Schnabel, Eds., 1997).この初版は，統合後間もない1992 年である.そこでは，学際的で実証的な理論と方
法に依拠する競技パフォーマンス（Leistung） 論, トレーニング (Training) 論, 試合 (Wettkampf）論の 3 領域が包含される（図 2).これ らは, 個別スポーツ理論・方法論々両輪関係にあ る一般トレーニング理論・方法論と呼ばれるもの で，国家スポーツシステムの理論体系の中では競 技スポーツの実践に対して直接的な貢献を果たす ベく中核的存在に位置付けられる（図 3).

トレーニング論は，トップレベルでの創造的で 総合的なスポーツトレーニングの実践活動と両輪 となり，トレーニングの実践過程の構造性，そこ で直面する諸問題と原因の所在の明示, 問題解決 への具体的方策，それらの原理的基礎の提起が目 指される。

本稿では，スポーツトレーニングの一般構成原 理の中心的内容でもあるトレーニング期分け (Training periodization) 問題に関して概括す る. 


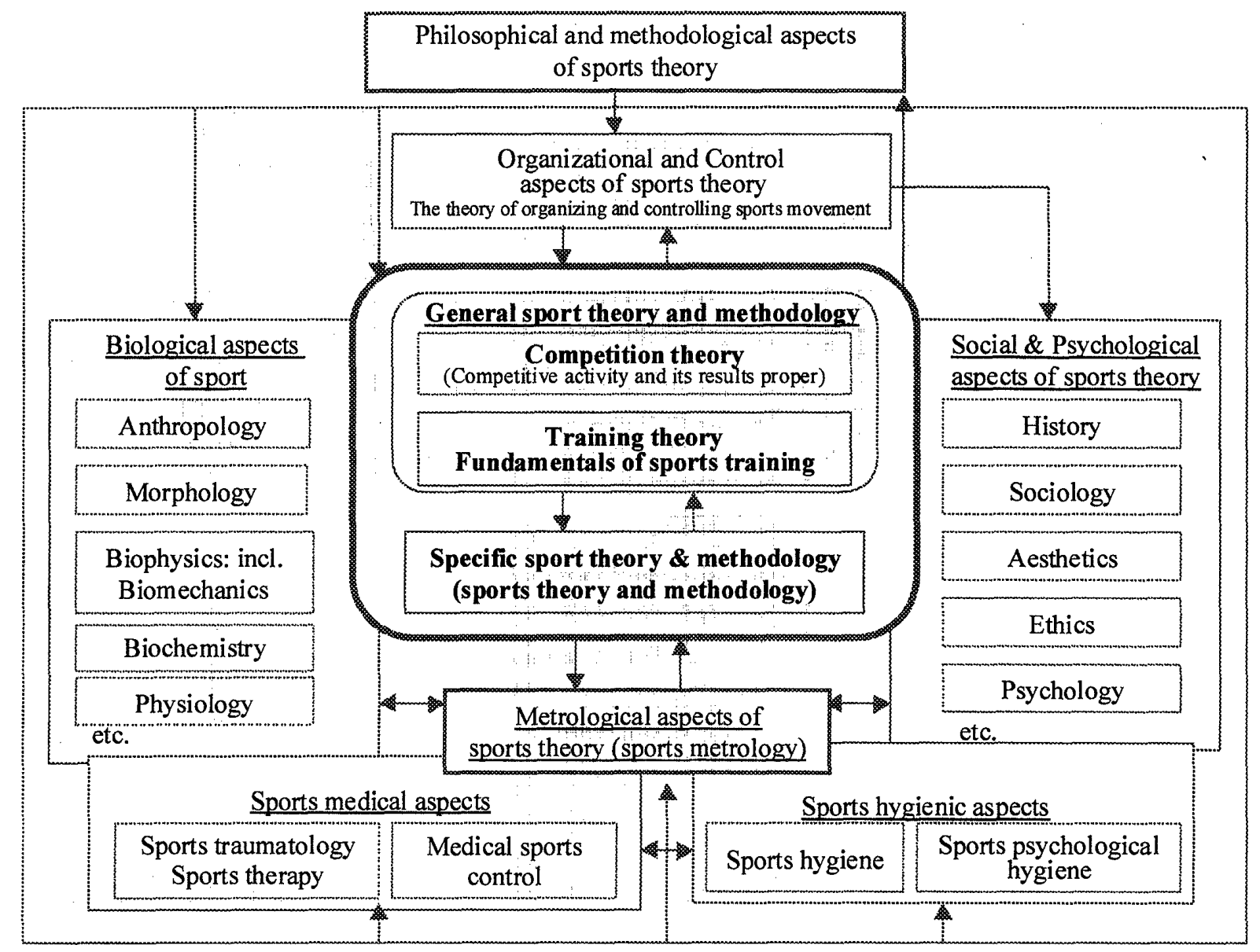

図 3 スポーツ理論の主要な分野と方向の構造モデル (Matwejew, 1981, p. 25より村木改変)

\section{2. 期分け論の背景と発展過程}

\section{1 期分けの本質的要因と諸条件}

トレーニング期分けとは，競技スポーツに於て 異なる目標設定とそれに伴った異なるトレーニン グ内容およびトレーニング負荷を持つ, 中程度の 期間にトレーニングを区分することである。この ことは，トレーニング周期全体の構造と組織的な 構成内容を包含している. Matwejew（1972，p. 38）はこの本質的要因を, 競技的状態（sport form）の周期的発達特性にあるとして，「一定の トレーニング周期の枠内に於けるトレーニングの 構成と内容の合目的的で周期的な变化」と定義し た、ロシア語での原著『スポーツトレーニングに お汀る期分けの諸問題』(Матвеев, 1965) の刊 行は, ドイツ語訳の公的出版の 7 年前に遡る.
近代オリンピックの誕生以来 1 世紀を経たが， 断絶の無い年間通してのトレーニング（yearround training）の考え方が一般的となったのは たかだか戦後の50年代以降のことである。その 間, トレーニング過程の周期化（期分け）問題を 理論的に認識し, 解決するに当たっては幾つもの 解釈が存在した。

Matwejew（1972，pp. 23-37）の指摘した主要 な意見の相違は，主としてトレーニング過程その ものの周期的变化（期分け）とその变化に影響を 与える要因に関してである。これらの主たる要因 は以下の 4 つに代表され，今日もな放分けの 論拠として一般に使われる場合が多い。

(1) トレーニングの果たすべき課題

(2) 試合日程もしくは季節・気候的要因

(3) トレーニングによる発達段階の適正化と身 


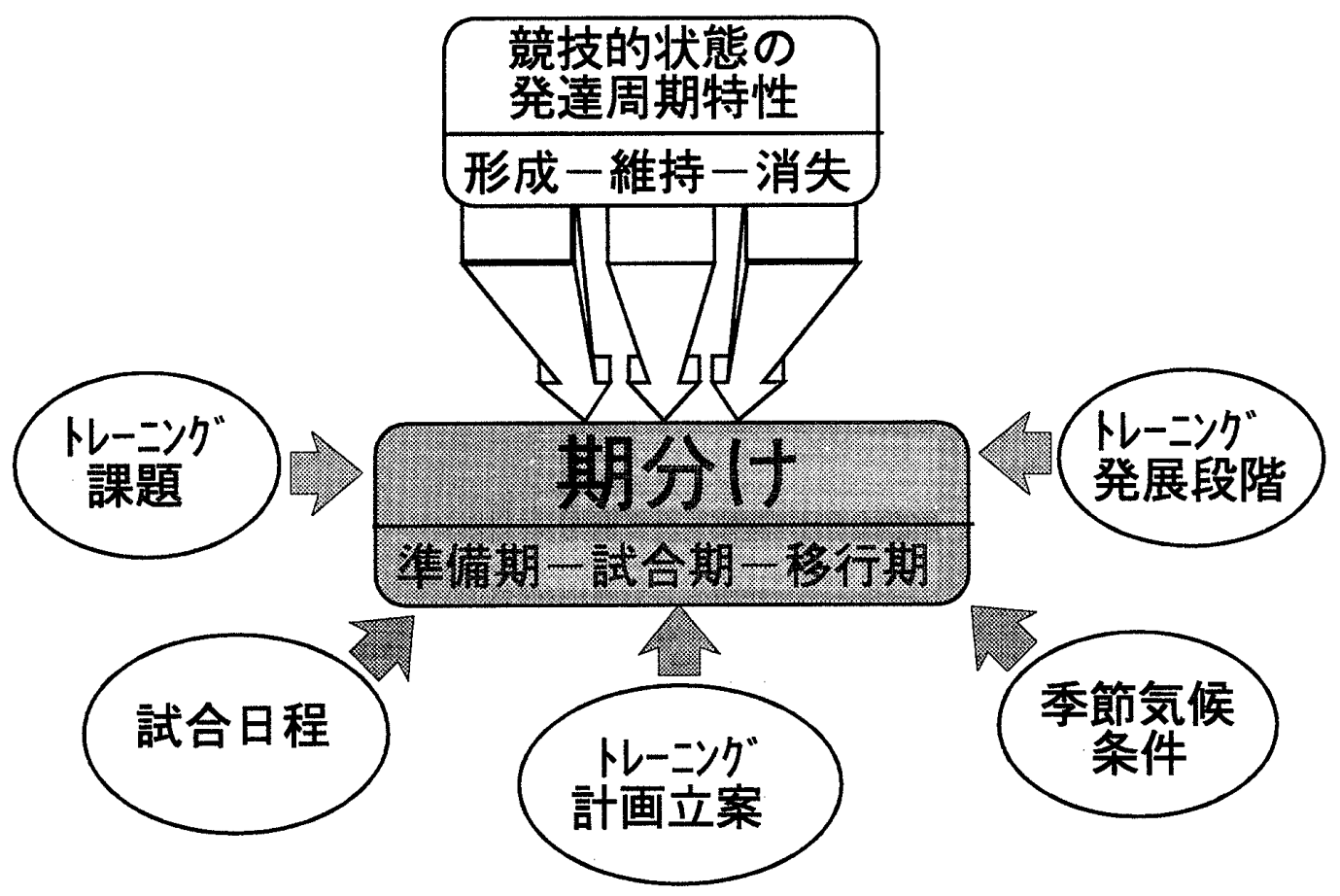

図 4 トレーニング期分けの本質的要因（競技的状態）と影響する諸条件の関係（村木作図）.

体器官の適応過程

(4) 試合に臨むコンディション調整の合法性

図 4 は, トレーニング期分けの本質的要因（競 技的状態）と影響する諸条件の関係を示してお り，上記を期分けの主要因とする考え方は図中の 黒矢印で示している.

これらを期分けの主要因とする解釈の相違は， 周期区分の数および名称にも反映されており，こ れらの背後には，しばしば本質的な違いが隠され ている，例えば，「試合期」を“主要期”として， 他をその主従関係もしくは副次的な位置付けを意 図した，準備のための「準備期」，「鍛錬期」，「仕 上げ期」，およびそれらの期の間に置かれる無数 の「過渡期」等の様々な区分名称である。また， 全体の周期の長さや各期の長さについては更に大 きな意見の違いがある：これらの解积は，いくつ かの矛盾した前提条件から出発している。例え ば，トレーニング計画の立案の便宜のため, 計画 と実際（真の変化）との混同，季節や試合日程へ の過度な依存等々である.

彼はこれらの伝統的解釈に対して，トレーニン グ期分け問題に関する分析の出発点を，その客観
的性格の事実確認に求めた，その理由は，幾つか の実証的データに基づく弁証法的批判を重ねるこ とで, 上記の考え方に論理的な矛盾を見出したた めである.

期分けの伝統的要因に関する彼の新たなパラダ イム転換は，その本質的要因として競技的状態 （sport form）の発達周期特性の存在を研究仮説 として設けた．競技的状態とは，「選手が適切な トレーニングを通じて多面的な準備がなされ，競 技的発達の新しい段階毎に到達する最高の力を備 えた状態」(Matwejew, 1972, p. 39） と定義され る。

トレーニング計画は完全なものではなく，遂行 された結果とも同じではない。このため，計画さ れた期分けに従って生じる真の変化（客観的期分 け）を計画と同一視することはできない. 計画が 目的を達成できるのは，トレーニング過程の客観 的合理性にかなっており，すべてが計画通りに進 行し, 特に期分けの発達周期特性に従っている必 要がある. 換言すれば，競技的状態の発達周期の 段階はひとりでに生まれるものではなく，合理的 なトレーニングの実践過程を通じてのみ合目的的 
に達成され得る，従って，トレーニング計画での 期分けの本質的要因は, 競技的状態の発達周期特 性に依拠すると考えたのである.

その背景には, 戦後急速に発展し, 国際競争が 激しくなったオリンピック競技を中心とするトッ プレベルスポーツでは，トレーニング構成を最適 化し，最重要試合に際してタイミング良く最高の 競技達成々安定性を確保することが求められてい たことにある。また，それまで期分けを決定づけ る主な要因とみなして来た季節気候的条件や競技 試合日程が，実際面で次第にその論理的矛盾を露 呈しつつあった．例えば，欧米での室内競技場等 のスポーツ施設の建設と普及, 夏冬逆転する南北 両半球に跨がった地球的規模でのスポーツ交流の 増大である。これらは，競技活動に対する季節。 気候的条件の制約からの解放を意味する。屯た， それらによって国際的試合日程の過密・長期化の 先駘けと共に, 最重要試合へのピーク・パフォー マンス形成に対しての種々の問題と矛盾が增大し つつあった。

当初の研究での競技的状態の客観的評価の方法 は，唯一の総合的指標とする競技記録の動態の分 析に基づいて，個々の選手の年間平均記録が判定 基準として用いられた。対象となったのは，競技 的発達過程の高次活動期間にある陸上競技, 重量 挙げ，水泳競技等の客観的計測競技種目でのソ連 および世界の一流選手約 900 名である。

それによると，連続する 2 年間の最高記録間 の平均間隔は，10.5-12 力月で0.3-3.5\%の記録の 向上が見られた。これは 1 年周期説の根拠とも 考えられるものであるが，事例的に個々の間隔を 検討すると，しばしばこの平均間隔とは異なる例 が見出された. $60 \%$ 以上の事例は 1 年間隔であ ったが，筋力・パワー的種目では半年間隔が多 く，持久的種目では逆に半年以内で最高記録を出 した例は殆ぞ無かった．特に，重量挙での間隔は 短縮傾向と共に，記録の著しい上昇傾向を示し た. また, 半年周期で記録の向上を続けた最長期 間の例は，重量挙げで 7 年半，陸上競技のパワ 一種目で 3-5 年半であった。これらの事実は, 年間トレーニング周期が伝統であるシーズン・ス
ポーツに於てさえ，幾人かの競技者の記録変動は 既に半年周期の傾向を示しつつあった.

これらの結果から導き出されたトレーニング面 への示唆は, 以下の様なものであった。 (1)筋力. パワー種目に対しては 1 年周期を否定するもの ではないが，年二重周期の適用価值が大きい。(2) 競技的状態の諸要素の本質的な改善には負荷量を 増大したり，動きの熟練度を養う長期にわたる順 応過程が必要となり，一般に半年周期は十分な期 間とは言えない。しかし，トレーニングの強度を 高めるための前提条件を作り出すには半年周期が 有効である. (3)スポーツ達成の向上性と安定性に とって，トレーニング周期が一定の順序に従って それぞれの競技的発達段階に適応している限り， 半年および 1 年のどちらの周期の適用も認めら れる。

当初の総合指標として用いられた年間平均記録 は，その後より詳細な記録動態の研究と共に新た な判定基準ゾーンが設定され，幾つかの安定性の 基準が追加されている（Матвеев 1974）。

競技的状態にあるとの判定は, 当該トレーニン グ・サイクルの枠内で, 記録を達成し得る「最高」 若しくは「最高に近い」トレーニング水準で, 年 間最高記録に対するマイナス $2 \%$ レ゙ルが用い られる.しかし，この基準は，同一スポーツ内で も陸上競技の様に種目間での競技特性の違いが顕 著な場合には，一律な設定には問題もある．筆者 はオリンピック，世界選手権等の最重要試合での 記録分析を通じて，跳躍・投てき種目の様な比較 的技術性の高いフィールド種目には，トラック競 技より 2-3\%低い值の適用を勧めている（村木， 1994,pp. 84-86). しかし, 実際には不完全な試 合日程などによって，適正な競技的状態の形成・ 維持が妨げられることも稀ではない.オリンピッ ク等の最重要試合に最高記録を出したものは僅か 15〜25\%に過ぎず，トレーニング計画はそれに 従って生じている真の変化とは必ずしも同じでは ないためである.

2.2 競技的状態の発達周期特性とトレーニング 競技的状態の獲得は, 体力面, 技術 - 戦術面, 
精神面での各諸要素諸細目に及ぶ多面的準備の過 程である. 競技的状態はこれら総てが調和して， 1 つの統一されたものに高められているのが特徵 的である. しかも，トレーニング水準の高い上級 選手ほど，トレーニングの特異性の増大と共に要 素間の対立も顕著となり，トレーニング過程で同 時に満足できない要素間の取捨選択もしくは調整 (trade-off) が求められる様になる.したがって, 競技的状態の発達周期の各期の長さは，競技者の トレーニングの開始時の水準, 年令, 個人的特 性，専門種目の特性等の事情に影響されるが，決 定的な要因はトレーニングであり，その習熟拉よ び適応過程の本質的原理によって決定付けられ る.

これらの関係を実証的に検討するには，訓練性 の高い上級選手対象に，計画と共に遂行された卜 レーニング自体の分析が不可欠である。このた め, 先ず, トレーニング構成の一般的な原理が一 種の仮説モデルとして準備される.仮説モデルの 導出は，これまでの経験理論々教育学，生物およ び医学的原理からの演繹的な援用に基づいてい る. 競技的状態の比較的安定した側面である体力 面は, 本質的には生物学的な適応過程の連続した
段階であり，トレーニング作用やその他の幾つか の要因によって生じる生理学的, 生化学的, 形態 学的転換の段階を表すとみなされた。

これらの基本原理は，(1)競技的状態の発達周期 特性，(2)基本的トレーニング手段としての運動の 一般性と専門性の相対的な相互関係，(3)それらの 負荷の量と強度の二面性，(4)負荷の動態の波状的 特性, (5)トレーニングの基本構造単位(ブロック) としてのマクロ，メゾおよびミクロ周期である.

トレーニング分析の具体化には，そこで用いら れる基本的手段としての運動（exercise）のカテ ゴリー化が不可欠でめる。このため，上り実用的 な観点から, 日常的に用いられる無数の基本的卜 レーニング手段としての運動自体が主要なタイプ に分類される．そこでは，個々の種目の試合運動 の基本的な運動形態及び機能的特徵を基準とする 相対的な類縁関係の観点から, 試合的, 専門的お よび一般的運動が大別される（図 5).

一方では，トレーニング過程を評価する目的の ために, 主要な運動は評価機能を付加し得る外的 指標の基準化がなされ，競技的状態の総合的指標 とは別に，その補足的・部分的な評価規準も不可 欠である.これらに関する生体の内的指標の多く

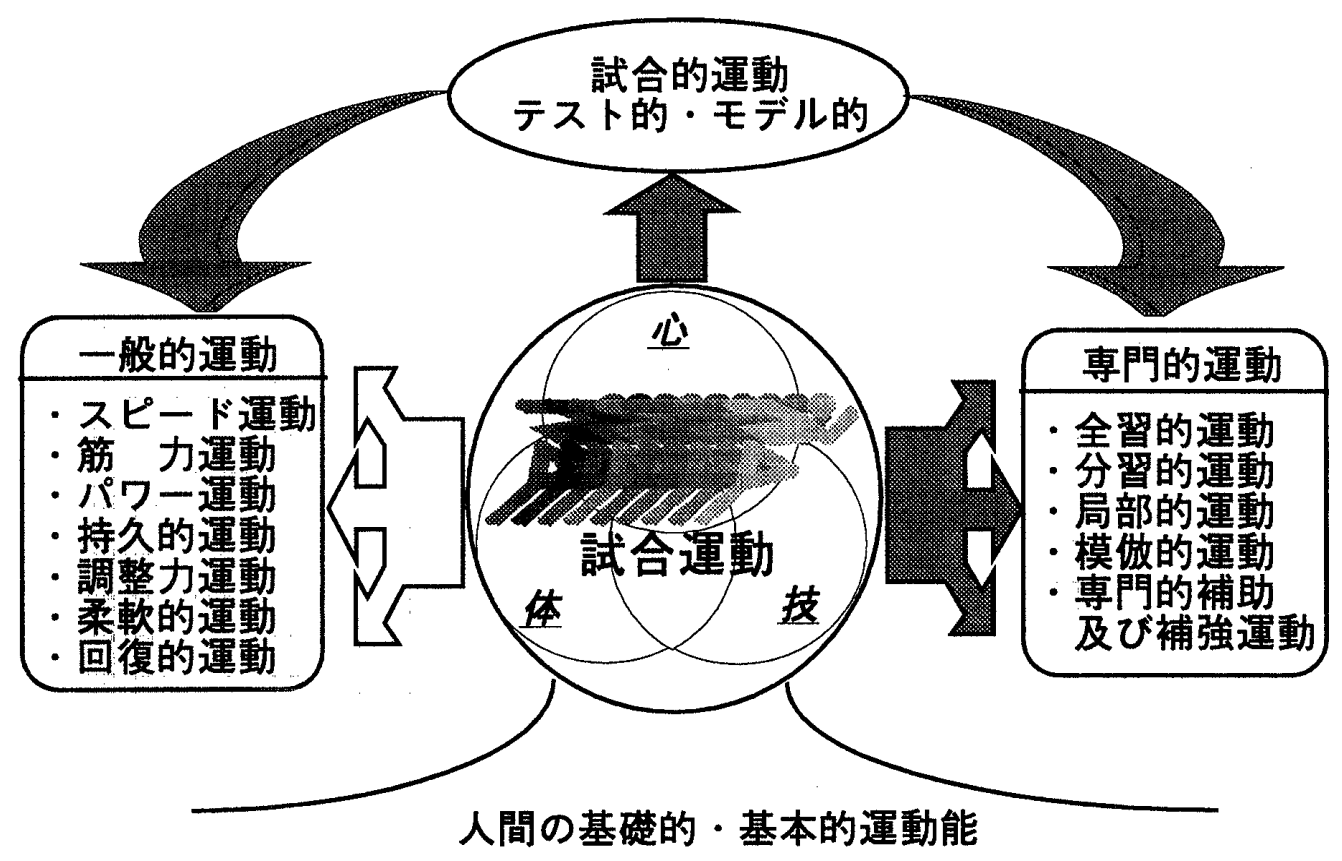

図 5 基本的トレーニング手段としての運動の分類（村木作図） 
は, 関連諸科学の個別研究成果と方法に依拠す る. その際，フィールドテストとして基準化され た運動は，トレーニングコントロールテスト（ま たは単にコントロールテスト）と呼んでいる。こ の根底には，理論的に扱われる要素的課題は，総 て運動に内在する不可分な一面的かつ相対的な特 徵を断片的に描写したに過ぎず, 総ての課題は運 動自体にあるとの実践的認識に立っているように 思われる：実際上，個別スポーツでの優れた選手 およびコーチは，トレーニングの実践過程で様々 な運動を発明し，それらを系統付け，習熟的もし くは強化的方向に巧及に使い分けている（村木 1994, pp. 137-139).

トレーニング運動の負荷は, 外的及び内的負荷 が区別されると共に，量と強度の二面性の概念が 設けられ定量的な段階付けがなされる. 負荷の強 度は, 運動に費やされる努力度合い, 緊張度およ び運動の各瞬間における負荷の集中度と密接に関 係し, 単位時間当りのトレーニング量京たは実行 されたトライアル数として定義される。これはま た，トレーヒソグ単位（全体めるいはより長い期 間）を特徵的に示すために量の指標から抜出し て, 回数 (ないし距離または重量) とトレーニン グ時間の商としても扱われる.

一方, 試合パフォーマンスは, 上級選手ほど大 観衆やメディアの面前での高度な競争条件の下で なされる著しい情緒的興奮を伴なった一種の臨界 出力でもあり, 日常的なトレーニングパフォーマ ンスとは顕著な差が認められる.ちなみに，上級 ウエイトリフターの試合とトレーニングでのベス ト記録間には $12.5 \pm 2.5 \%$ もの差が見られる（Zatsiorsky, 1995, p. 86).このため, 特に試合に関 しては「試合負荷」と呼び，トレーニング系と試 合系での負荷を区別している．また，技術的・戦 術的側面を主なトレー二ング内容抢よび課題とす るものでは, 試合負荷と同様, 暫定的なものとし て等級ならびに点数化の利用や，選手の自己評価 に基づくものも指標に含めている.

この様に定義された強度は, 便宜的な客観的尺 度が準備されてはいたが，その本質は単なる機械 的な出力のパラメーターではなく, 極めて主観的
な努力度や緊張度に依拠している. 従って, 強度 問題は特殊な試合負荷問題と共に, 最高パフォー マンスの発揮に不可欠なリラクセーション問題お よび運動質とも関連して多くの研究課題が残され ている（村木，1994, pp. 157-160).

\section{3 トレーニング構成の一般原理}

一連のマトベーエフ研究の結果, 期分けの本質 問題に関して共通する, ある種の客観的性格（自 然法則性）が認識されることになる.これらは， 相互に関係しあうトレーニング構成の一般的原理 として以下の6つに集約される (Matwejew, 1972, pp. 73-107; 1977, pp. 64-82).

(1) 最大化への指向性抢よび専門化, 個別化

(2) 一般的及び専門的訓練の相互関係の統一と 適正化

(3) 負荷と回復の組織的変化によるトレーニン グ過程の連続性

(4) トレーニング課題と負荷の漸進性

(5) トレーニング負荷の量と強度の二面性と変 化の波状性

(6) トレーニング経過における競技的状態の発 達周期性

一般的原理が構筑される一方で, タイプの異な るスポーツ種目毎で, 競技的状態の発達周期が持 つ特殊で具体的な実体構造と共に，その法則性が 実体の属性として認識される必要がある。また， このことは, 長期の競技的発達過程の各段階にも 該当する.マトベーエフはこの問題について，ト レーニング期分け特性の観点からスポーツ種目の 分類試案を提示すると共に，それぞれのタイプ別 および長期の競技的発達過程における各段階の特 性一特にシュニア期の問題について, 今後の研究 の重要性を示唆している (Matwejew, 1972, pp. 195-200).

一連のマトベーエフ研究は, 今日では単に「期 分け論」と総称される場合が多い。しかし，彼が 後に上梓する『一般スポーツトレーニングの原理』 (Матвеев, 1977; Matwejew, 1981, Matvejev, 1981 ; マトヴェイエフ，1985）で示される様に, それは一連の研究の端緒であり, 中核問題ではあ 
ったが，トレーニング構成の一般原理を論ずる際 の一部に過ぎない．また，実証的研究の方法論的 な制約から，扱われた内容の多くは定量化し易い 体力面の要素的内容が中心でもあった。

同時代，マトベーエフの期分け問題の研究と並 行して, 体力問題に特化した研究の存在も無視で きない，それらの著作の多くは，数年内に欧州各 国語へ翻訳されている.ドイツ語翻訳の出版の代 表例は，Zaciorskij (1972)，Werchoshanski (1972), Кузнецов (1975) らである.ザチオルス キ一（1972）は，日本でも「スポーツマンと体 力」の著者として知られるが，初めて競技体力の 構造と方法を体系的に網羅した，後二者は，主に スピード・筋力問題を中心に，高度にトレーニン グされた上級選手固有の専門的体力の構造と方法 に焦点を当てている.

これら一連の実践的理論研究は，ソ連の国際的 なスポーツ実績と共に各国のスポーツ指導者や理 論家の関心を集めることになる．本格的なメディ ア化と共にオリンピックでの国際競争が激化した 70 年代には，成功を収めたり連型スポーツシス テムの導入が多くの西側諸国でも推進される.ナ ショナルトレーニングセンター，公認コーチ養成 およびエリート選手の選抜，養成（支援）制度等 々である，その様な過程の中で，一般および個別 トレーニング論関連の著作抢よび紹介論文も各国 で相次いで登場する，その端緒となったのが，マ トベーエフの原著に記載された競技記録の動態に 関する西ドイッでの追試的論文の揭載であり，こ れは同年末に米国の専門誌でも翻訳掲載された (Krüger, 1973)。主な一般トレーニング論書籍 は，東独での Harre（1971，1975，1979）および Zannon (1981)， ポーランドでの Ulatowski (1973)；，西独のMartin $(1979,1980)$ および Starishka (1988)，英国での Dick (1980)，ルー マニアからの移住者でもあるカナダでの Bompa (1983, 1993), ウクライナの Платонова (1987) 等である、また，80年代半ばまでには，相次い でソ連および東独の一般トレーニング論の英訳版 およびソ連のスポーツシステムの紹介が出版され る (Riodan, 1977, Tayler, 1977, Schneidman,
1980; Matvejev, 1981; Harre, 1982; Kukushkin, 1983).

また，米国では，ストレングス\&コンディショ ニングコーチらの機関紙, National Strength and Conditioning Association (NSCA) Journal (1978 創刊）等を通じた期分け理論の紹介が相次ぐ (Pedemonte, 1982a, 1982b, 1983, 1986a, 1986b, 1987; Roundtable, 1986a, 1986b, 1987, Yessis, 1983; Pauletto, 1986)。また関連書の出版も重な り (Freeman, 1989, Yessis, 1987; Bompa, 1983, 1993），遅れ馳せながらトレーニング指導者およ び実践理論家の間で期分け論に関心が集まって一 種の流行現象を呈している。この傾向は，上級選 手の専門的（特殊）体力問題に関しても同様で, ソ連時代の体力関連論文を集めた翻訳掲載誌 Soviet Sports Review（旧名 Yessis Review 1966-78, 1994年廃刊）がそれらの紹介に大きく貢献する.

\section{3. 期分けトレーニング論の批判}

80年代の半ば以降，世界標準ともなった期分 け論を核とする一般トレーニング論に対して，次 第に疑問と批判が生まれる。主にそれらは，トッ プレベルスポーツの実践現場を預かる上級コーチ と理論家からである。これらに共通する点は，マ トベーエフ理論が急速に発展した世界的なトップ レベルでのスポーツ活動の実体に即さなくなった との批判である.

これらの論拠の背景には，第 1 に，最近 20 年 間に多くの種目で，オリンピック大会以外にも世 界選手権やワールド・カップ等, 毎年の様に大規 模な国際大会が連続することでトップレベル選手 の試合の過密・長期化が指摘される (Tschiene, 1979, 1985; Werchoshanskij, 1981, 1982, 1984). 第 2 は, プロフェッショナル化したキャリア選 手の増大と競技的発達段階の成熟化に伴って深化 したトレーニング内容の高度な専門化である。

一方，「今日，我々が知るトレーニング期分け の概念はマトベーエフ研究に始まり，厳密にトレ 一ニング管理されたり連・東欧圈の理論と実践を 通じて形成されたものである．ソ連・東欧圏での トレーニング管理は, 選手のトレーニングから試 
合の数やタイプに及び，中央機構からの厳密な指 導によって初めて効果的に達成されたものであ る. 従って, 異なった社会的スポーツ環境の下 で，このトレーニング期分けの概念を応用する場 合には，この背景が考慮される必要がある」との 批判も見られる（Gambetta, 1989)。

選手に最適に準備された状態を求め，高度なス ポーツ・パフォーマンスを維持するために，必要 な水準でトレーニングを継続するには多くの矛盾 した状況が生じているためである。選手が当該種 目で一旦高度な国際水準に到達した際には, 試合 そのものがトレーニング刺激の最高の手段・方法 でもある。しかし，これはまた，故障の発生リス クを高めると同時に，選手キャリアをより短くし がちでもある. また，年 2 サイクルの期分けモ デルでさえも，一般的訓練内容への過㮃な配分 は，トップレベル選手に対してしばしばマイナス 効果をもたらしているとの認識がある．この傾向 は，特にスピード・筋力系抢よび球技系種目に顕 著であり，最近の実践面では，全体的に専門的準 備期と試合期の構成内容に絞られたモデルとなっ ているのが特徵的である. そこでのトレーニング 内容は, 専門種目と同様な運動のメカニズムに結 びついたタイプの専門的運動により大きな割合が 占められるようになる (Tschiene, 1979, 1985).

競技的状態の発達周期の適正期間の長さは，専 門とするスポーツ種目の特性だけでなく, 競技者 のトレーニング開始時のレベル, 年令, 個人的特 性によっても影響され，幾つかのバリエーション が見られる。発達過程の初期（ジュニア期）にあ っては，トレーニングの急速な発展が特徽的であ る.一方, 高次活動段階にあるトップレベル選手 （シニア）では，身体機能の可能性は安定化する 中で, 機能的な全体的な結合協調関係の改善が細 部にわたって促進されることになる，また，身体 的発育過程にも多くの個人差があるように, トレ 一ニングによる順応適応過程の長さでも個人差を 無視することはできない（Tschiene, 1985; Werchoshanskij, 1984).

この様な理由から，初期の発達段階にあるジュ ニア期でのトレーニング期分けとトレーニング内
容は, シニア期に要求されるほど厳密なものでは ない. そこでは, トレーニング周期全体が, 構造 的特徵として諸要素の全面的な発達を目指す方向 に抢かれ，試合期にも準備期的な性格が保たれる ことになる．従って，試合日程もシニアに比べ, 試合間隔を長くとり，試合密度を抑える必要があ る。すた，試合そのものも全体にトレーニング的 性格が特徽である.

高次活動期間の後半にあるトレーニング性の高 いベテラン選手では，準備期において，特にその 第 1 段階での一般的なトレーニング内容は大幅 に減少し，全体により専門化された強度の高い内 容と, 試合および積極的回復を目的としたものと なる，そこでは，多様な数多くの試合参加が実現 され，試合期の大幅な延長も可能である．マ・卡 一エフの古典的モデルは，上級者でも比較的初期 のトレーニング段階の者には依然有効であるが， ベテランのトップレベルでは周期間の厳密な期分 けは不鮮明となる傾向にある。これは，選手のト レーニング性が高まるに連れて年間を通じて専門 的訓練の割合が増大し，専門的訓練で求められる 負荷量・強度共に, 年間トレーニング全体が著し く高いレベルに達するためである.

これらの問題は, ドイッのトレーニング科学専 門誌 “Leistungssport”（1971年創刊）を中心に 見ると，相互に関連しながらも次の 3 つのタイ プに分けられる：(1)類型的種目特性および発達段 階特性への対応問題, (2)集中方式々要素的課題へ の対応（trade-off : 同時に満足できない諸条件の 間の取捨選択 〔調整〕) 問題, そして(3)実際的卜 レーニングに対しての分析的なトレーニング論へ の懐嶷一即ち,より実践的で統合的なトレーニン グ論の模索である.

第 1 の批判である類型的種目特性と発達段階 特性への対応問題は, 主にスピード・筋力 (パワ 一）系の種目に関連してなされた. マトベーエフ の期分け論を支えた実証的データが，主に持久系 種目であったためである。 また，研究対象となっ た当時（1950-60年代初期）のトップレベル選手 の競技水準自体も批判される. そこでは, 後の急 激な競技レベルの向上と選手キャリアの長期化 
で，今となっては系統発生的な発達途上段階に相 当し,最近のトップレベルの実体にそぐわなくな った点が主張される。これは, 世界規模での国際 試合の過密 - 長期化から, 競技的状態の周期構造 が比較的短期間に年間複数回更新されると同時 に，極めて多様性に富み得ることに論拠を置いて いる (Tschiene, 1985; Werchoshanskij, 1982, 1984)。しかしながら，いずれも論証するに足る 実証的データは得られていない。

また，第 2 の批判は，上記の批判とも関連し たもので，トップレベル選手の活動実体の変革を 論拠にした，マトベ一エフの古典的負荷変動の一 般モデルに対するものである。そこでは，主に体 力面のスピード・筋力要素に注目した集中方式 (Werchoshanskij, 1984) もしくはブロックシス テム (Tschiene, 1985, Satori, 1987), 同時に満 足できない要素的課題間の取捨選択または調整 (trade-off) 問題への対応策として半メゾ周期で のコントロール等が提起されている（Zatsiors$\mathrm{ky}, 1995)$.ごく最近では, マトベーエフの期分 け論に関連して旧ソ連のトレーニング論体系を全 面否定する過激な批判も登場する（Verchoshanskij, 1998).

これらの批判の多くは, Platonov (1999) や Bartonietz (1999) の并護的反論にも見られる様 に，当初のマトベーエフ研究の期分け論およびそ れから発展した一般スポーツトレーニング論の包 括的内容の一部を，しかも一面的に取り上げた偏 向的内容で，実証的データにも乏しい。 また，そ れらの多くは, 当時の研究上の限界若しくは今後 の研究課題として，既にマトベーエフが指摘した ものばかりである.

第 3 の批判は，これまでの伝統的な分析的科 学の方法論に依拠するトレーニング論自体への懐 疑である.この理由は, 実際のトレーニングで は, 一つの運動（exercise）が，種々の条件によ って指向される様々なトレーニングの狙いや課題 に対応して，吅みに使い分けられている事実から 出発している：例えば，最初に技術や戦術を指向 して習熟的方向に用いられた運動が，次には体力 面を指向して強化的方向に使われる（またはその
逆). 換言すれば，トレーニング理論（科学）に おいて，運動を細分化した一面的で要素的に扱わ れる内容自体，決して実存するものでなく，運動 自体からそれらを取り出すこともできない，理論 的に区分される体力，技術，戦術および心理トレ 一ニング若しくはそれらの個々の一面的な要素自 体，理論的に扱うための便宜上の区分に過ぎず，

トレーニングの実際との乘離に対する疑問と批判 でもある（村木, 1994, pp. 137-139）.

これらの本質は，運動自体が持つ不可分な多面 的，複合的要素を損なわないで，それらの指向性 を競技パフォーマンス向上のために合理的に使い 分け，全体性を持つ運動を如何に統合的，相乗的 に作用させ得るかを問う，より実践的で統合的な 新しいトレーニング論の模索にある（Zannon, 1997; Gambetta, 1989).

この意味では, 従来から典型的な技術・戦術卜 レーニングとして一面的に扱われてきた代表的運 動を，体力面との二面性の観点から取り上げた球 技系種目を対象とする Saßら（1997）抢よび対 人系格闘技種目のLehmann (1997) らのものは 新しい研究動向の一端を示すものと言えよう。ま た，現象論的分析とはいえ，球技系での試合運動 からランニングパターンを類型化し，コンディシ ョントレーニングへの反映を意図した Plisk and Gambetta (1997), Wroblewski (1997) らの取り 組みも実践的なトレーニング論として意義あるも のと言えよう。

一方, 競技パフォーマンスに体力面の因子が大 きいとされる陸上競技でも，特に，比較的技術面 の影響が大きいとみられるスピード・筋力種目で は, 理論と実践両面で両者の関係が注目されてき た. その代表例が，スプリント，跳躍および投擲 種目での負荷軽減法（assisted training）である （村木，1994, pp. 121-128）.これらの背後には， 高度なトレーニング水準に到達したキャリア選手 の非日常的な試合負荷条件の下での最大出力（全 力）発揮問題が存在する．換言すれば，極めて主 観的な強度問題とその際の「脱制止」もしくは「抑 止現象の防止」または臨界出力時のリラクセーシ ョン問題である. 


\section{4. まと め}

マトベーエフの期分け論を契機に発展した一般 スポーツトレーニング論は, 個別スポーツ種目 （特に，陸上競技，重量挙，水泳競技なぞ）の個 人種目での高度な実践活動を通じて生久出された 経験理論の発展と，教育学㧍よび生物・医科学系 の基礎的研究成果の応用によって発展してきた。 今日では，横断的な視座の下に学際的にそれらの 研究方法を駆使しながら，多様なスポーツ運動に 共通する問題を扱うスポーツ科学の中核としての 存在が期待される. その存在は，個別スポーツの 理論的な発展と両輪関係である必要がある。なぜ なら，個別スポーツ種目に掠けるパフォーマンス の発達は，一般スポーツ運動能力ひいては日常生 活運動の発達を土台にした高度な專門化もしくは 特殊化の過程だからである。むた，理論化の作業 自体，個別の特殊な事例加ら一般的な法則性を見 出す帰納的推論と, いくつかの前提から $1 \supset 9$ 結論を導く演繹的推論に依抛する普遍化の過程に 他ならないためでめる。

前述した最近の期分け理論批判の幾つかは，現 状の成熟化したトップレベルスポーツの実態を反 映したものとして共感し得るものがある。しか し，急激に過密・長期化した世界規模での大会が 毎年のように連続する試合日程は，競技的状態の 向上性と安定性を必ずしも保証する訳ではなく， むしろその様なトレーニングの合理性とは無関係 な興行的関心に依拠するところが大である。それ らに対しては，十分な論抛を持ったトレーニング 論側からの批判が不可欠であり, 試合システム自 体の研究と共に，マトベーエフが行ったと同様な 試合パフォーマンス動態の追試が改めて求められ る.

一方，競技パフォーマンスの向上を目指して取 り組むスポーツトレーニングでの包括的かつ統合 的内容は，トレーニングの断片的要素を幾ら集め ても，その体系化は為し得ないであろう.トレー ニング論研究では,不完全ではあっても包括的な トレーニング体系全体の構造化と共に，そこでの 問題の所在を見出し, 本来的な運動の多面的現象
を出来るだけ損なわずにその本質が明らかにされ る必要がある。こうした意味からも，古典と言わ れるマトベーエフの期分け論の出発点となった競 技的状態の本質の客観的事実認識が改めて求めら れる。

そこでターゲットにすべき研究課題は，相互に 関連しあう次の 3 つの領域に大別される。帛れ らは, (1)スポーツパフォーマンス問題, (2)スポー ツトレーニング問題, (3)試合問題である。これら は，個々のスポーツ種目（もしくはある程度カテ ゴリー化された系毎）に特化された個別理論と， 横断的にそれらの共通問題を扱う一般理論との両 輪関係での発展が望まれる。

\section{文献}

Bartonietz, K. (1999) Das vermeintliche Ende der "Periodisierung" oder Ansätze zur Weiterentwicklung des Trainings. Leistungssport 1: 16-17.

Bompa, T. O. (1983) Theory and methodology of training. Kendall/Hunt Publishing.

Bompa, T. O. (1993) Periodization of strength - the new wave in strength training. Veritas Publishing, Inc.

Dick, F. W. (1980) Sports training principles. Lepus Books: London.

Freeman, W. H. (1989) Peak when it counts-Periodization for American track \& field, 1st edition. Tafnews Press.

Gambetta V. (1989) New trends in training theory. New Studies in Athletics 4(3): 7-10.

Harre, D. (Red.) (1971) Trainingslehre-Einfürung in die Theorie und Methodik des sportlichen Trainings. Sportverlag: Berlin.

Harre, D. (Eds.) (1982) Principles of sports trainingIntroduction to the theory and methods of training. Sportverlag: Berlin.

Krüger, A. (1973) Periodization, or peaking at the right time. Track Technique 54: 1720-1724. < Krüger, A. (1973) Periodisierung und Selektion der Leichtathleten im Olympiajahre Leistungssport 3(2): 91-99.>

Kukushkin, G. I. (Eds.) (1983) The system of physical education in the USSR. Raduga Publishers: Moscow. 〈Кукушкин, Г. И., (Ред.) (1975) Советская Система Физического Воспитания. Физкультура и Спорт: Москва.> 
Кузнецов, В. В. (1975) Специальная силовая подоготовка спортсмена. Физкулътура и Спорт: Москва.

Lehmann, G. (1997) Einheit von Technik-Taktik und Kondition. Leistungssport 3: 12-17.

Martin, D. (1979) Grundlagen der Trainingslehre (Teil I) Die inhaltliche Structur des Trainings-prozesses. Verlag Karl Hofmann, Schorndorf.

Martin, D. (1980) Grundlagen der Trainingslehre (Teil II) Die planung, Gestaltung, Steuerung des Trainings und des Kinder- und Jugendtraining. Verlag Karl Hofmann, Schorndorf.

Матвеев, Л. П. (1965) Проблема периодизации спортивной тренировки. Физкулътура и Спорт: Москва.

Matwejew, L. P. (1972) Periodisierung des sportlichen Trainings. Bartels \& Wernitz.

Матвеев, Л. П., Калинин, В. К., Озолин, Н. Н. (1974) О характеристиках спортивной формы и некоторых путях рационализации структуры соревнователъного периода. In: Матвеев, Л. П. (Ред.) Совершенстование системы подготовки спортсменов (Проблемы построения тренировки). Государственныи центральный ордена Ленина институт физической культуры: Москва. pp. 4-22.

Матвеев, Л. П. (1977) Основы спортивнои тренировки. Физкулътура и Спорт: Москва.

Matvejev, L. P. (1981) Fundamentals of sports training. Progress Publishers: Moscow.

Matwejew, L. P. (1981) Grundlagen des sportlichen Trainings. Sportverlag: Berlin.

マトヴェイエフ：江上修代訳（1985）ソビエトスポー ツ・トレーニングの原理. 白帝社.

村木征人 (1994) スポーツ・トレーニング理論. ブッ クハウス $\mathrm{HD}$.

Pauletto, B. (1986) Periodization-Peaking. NSCA J. 8(4): 30-31.

Pedemonte, J. (1982) Updated acquisitions about training periodization (Part 1). NSCA J. 4(5): 56-60.

Pedemonte, J. (1982) Updated acquisitions about training periodization (Part 2). NSCA J. 4(6): 42-47.

Pedemonte, J. (1983) Updated acquisitions about training periodization (Part 3). NSCA J. 5(2): 29-34.

Pedemonte, J. (1986) Foundations of training periodization Part 1. NSCA J. 8(3): 62-65.

Pedemonte, J. (1986) Foundations of training periodization Part 2. NSCA J. 8(4): 26-28.

Платонова, В. Н. (1987) Теория спорта. Вища школа: Киев.

Platonov, V. (1999) Die konzeption der "Trainingsperiodisierung" und die Entwicklung einer Theorie des Trainings, Ein Diskussionsbeitrag. Leistungssport 1: 13-16.

Plisk, S. S. and Gambetta, V. (1997) Tactical metabolic training - part 1. Strength and conditioning. NSCA J. 19(2): 44-53.

Riordan, J. (1977) Sport in Soviet society. Cambridge University Press.

Roundtable (1986) Periodization Part-1. NSCA J. 8(5): 12-24.

Roundtable (1986) Periodization Part-2. NSCA J. 8(6): 17-24.

Roundtable (1987) Periodization Part-3. NSCA J. 9(1): 16-26.

Saß, H., Vietinghoff, A., Stoll, R. (1997) Zur Verknüpfung konditioneller und technischer Inhalte im Sportspieltraining als wesentliches Element einer ganzheitlich orientierten Trainingsauffassung. Leistungssport 3: 4-11.

Satori, J., Tschiene, P. (1987) Die fortentwicklung der Theorie das Trainings. Leistungssport 2: 7-16.

Schnabel, G. (Hrsg.) (1997) Trainingswissenschaft: Leistung-Training-Wettkampf. Sportverlag: Berlin.

Shneidman, N. N. (1980) Soviet road to Olympus-Theory and practice of Soviet physical culture and sport. Coaching Association of Canada.

Starishka, S. (1988) Trainingsplanung. Hofmann-Verlag Schorndorf.

Taylor, J. (Ed) (1977) Post Olympic Games symposium. Coaching Association of Canada.

Tschiene, P. (1979) The distinction of training structure in different stages of the preparation of athletes. In: Terauds, J., Dales, G. G. (Eds.) Science in Athletics. Academic Publishers. pp. 277-281.

Tschiene, P. (1985) Veranderungen in der Struktur des Jahrestrainingszyklus. Leistungssport 5: 5-12.

Ulatowski, T. (1973) The theory of sports training. I.O.C.

Werchoshanskij, J. W. (1972) Grundlagen des speziellen Krafttrainings. In: Adam, K. and Werchoshanskij, J. W. Modernes Krafttraining im Sport. Barels \& Wernitz: Berlin (pp. 37-43).

Werchoshanskij, J. W. (1981) Zur modellierung des Training in den Schnellkrart-Disziplinen der Leichtathletik. Leichtathletik 15(14): 499-502. 〈Jerкая атлетика 9: 10-11. 1980> 
Werchoshanskij, J. W., Mironenko, I. N., Antonova, T. M., Chačatrjan, O. W., Nikitin, S. W., Levčenko, A. W. (1982) Entwicklung eines Modells des Leistungszustands von Sportlern im Jahreszyklus und seine Bedeutung für die Trainingssteuerung Leistungssport 5: 363-366.

Werchoshanskij, J. (1984) Der langfristig verzögerte Trainingseffekt durch konzentriertes Krafttraining. Leistungssport 3: 41-42.

Werchoshanskij, J. (1992) Ein neues Trainingssystem für zyklische Sportarten-Ein neuer Weg der Gestaltung und Programmierung des Trainingsprozesses. Philippka-Verlag.

Verchoshanskij, J. V. (1998) Das Ende der "Periodisierung" des sportlichen Trainings im Spitzensport. Leistungssport 5: 14-19.

Wroblewski, G. (1997) Football running patterns. Strength and conditioning. NSCA J. 19(4): 44-49.

Yessis, M. (1983) Trends in Soviet strength and con- ditioning. NSCA J. 5(1): 45-46, 5(2): 64-65.

Yessis, M. (1987) Secrets of Soviet sports fitness and training. Arbor House.

Zaciorskij, V. M. (1972) Die Körperlichen eigenschaften des Sportlers. Trainerbibliothek Bd. 3. Berlin. 〈Зациорский, В. М. (1970) Физические качества спортсмена. Физкулътура и Спорт: Москва.

ザチオルスキー，V. M. : 渡辺謙訳 (1972) スポーツマ ンと体力. ベースボール・マガジン社.

Zatsiorsky, V. M. (1995) Science and practice of strength training. Human Kinetics.

Zanon, S. (1981) Grundlagen des sportlichen Trainings. Sportverlag: Berlin-Ost.

Zanon, S. (1997) Die alte "Theorie des Trainings" in der Kritik. Leistungssport 3: 18-19.

(平成 11 年 3 月 23 日受付 平成11年 3 月 25 日受理 